Shafique N. Virani

\title{
Een oude man, een tuin en een gezel- schap van moordenaars: legendes en werkelijkheden van de Nizari Ismaïlieten
}

\author{
Vertaald door Puck Brouwers, Fouad el Ghamarti, Hanneke \\ de Boer en Marianne Verheyen.'
}

Eeuwenlang hebben Marco Polo's legendes over de Oude Man van de Berg, zijn paradijselijke tuin en zijn gezelschap van moordenaars lezers gefascineerd. Huidig onderzoek heeft echter aangetoond dat deze legendes niets meer zijn dan fantasierijke vertellingen over de geschiedenis van de nizari ismaïlieten uit Alamoet. De herontdekking van lang verloren bronnen werpt nieuw licht op de nizari ismailieten en onthult het leven van een gemeenschap die even fascinerend, maar minder fantastisch was dan de 'moordenaars' van Marco Polo's verbeeldingskracht.

I. Er was eens een slechte prins ...

'Mulecte is een land waar, zo zegt men, een zekere kwaadaardige prins, die de Oude Man van de berg werd genoemd, lang geleden leefde..."

Zo luidt het begin van Marco Polo's verslag over een geheim genootschap van Assassijnen en hun leider: de Oude Man van de Berg.

$\mathrm{Na}$ teruggekeerd te zijn van zijn vierentwintigjarige verblijf in Azië, werd de onverschrokken Venetiaanse reiziger in 1298 gevangen genomen in Genua, waar hij Rustichello van Pisa ontmoette, een getalenteerde romanschrijver. 
Virani

Toen Marco Polo in de gevangenis zat vertelde hij over de fascinerende details van zijn eigen reizen, evenals over verhalen die hij van anderen had gehoord tijdens zijn reis (zoals afgebeeld in een schets van Quinto Cenni, fig. 1). ${ }^{3}$ Rustichello van Pisa schreef deze verhalen op en voegde daarnaast zijn eigen verhaallijnen toe.

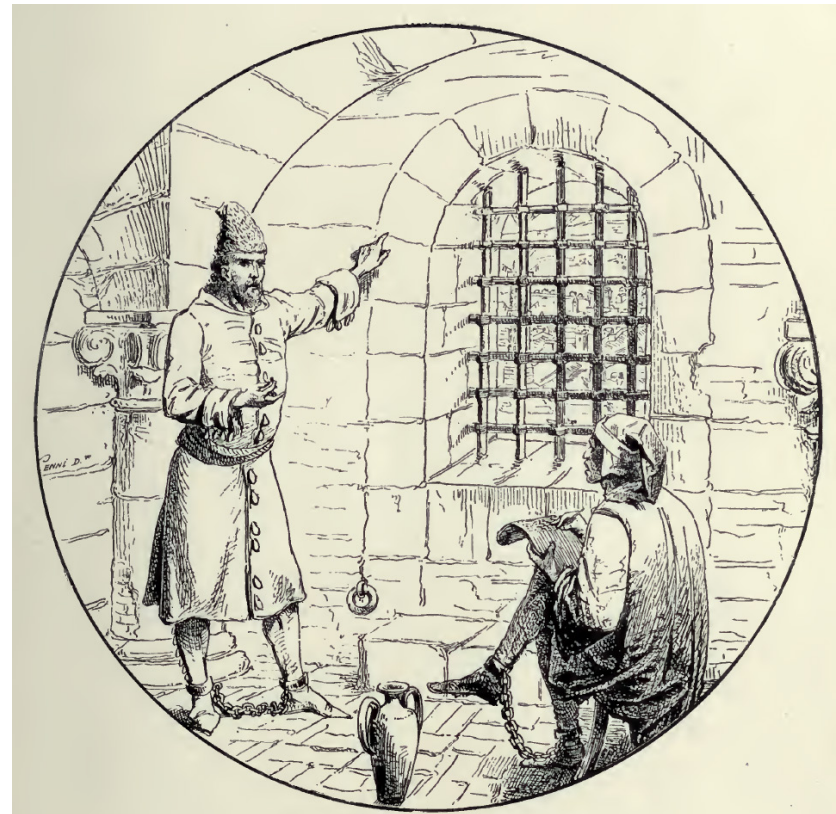

Figure 1. Marco Polo in the gevangenis van Genua, dicteert zijn verhaal aan Rustichello van Pisa.

De Oude Man, zo vertelt Marco Polo ons, 'werd in hun taal Alaodin genoemd':

Hij woonde in een zeer grootse en indrukwekkende vallei, ingesloten tussen twee zeer hoge bergen. In deze valleituin heerste een vreugde door de overvloed aan planten, bloemen, vruchten en bomen uit alle windstreken van de wereld. Hier had hij de mooiste huizen en paleizen laten bouwen die de wereld ooit gekend had, in prachtige verscheidenheid want ze waren allemaal verguld en versierd in azuur... Bovendien had hij in die tuin vele prachtige fonteinen laten maken... door sommige daarvan stroomde wijn, door sommige melk, door sommige honing en door andere het helderste water. Er woonden dames en jonkvrouwen, de mooiste ter wereld, die allen 
erg bekwaam waren in het bespelen van muziekinstrumenten. Zij zongen rond de fonteinen, op de juiste toon en dansten liefelijk, beter dan alle andere vrouwen van de wereld. Zij waren bovenal getraind in het bespelen en verleiden van mannen... De Oude Man liet zijn volgelingen zien dat die tuin het paradijs was.

De Oude Man had echter een duister motief voor het creëren van zijn paradijstuin, met flirtende jonkvrouwen en stromen van wijn, melk, honing en water. Marco Polo vertelt ons dat de Oude Man onbevreesde moordenaars wilde creëren, assassijnen genaamd, die de moed zouden hebben om zijn vijanden om het leven te brengen. Over zijn kwaadaardige plan schreef Marco Polo het volgende:

Soms plaatste de Oude Man, wanneer hij wenste een heer te doden waarmee hij in conflict was, een aantal van deze jongeren [die hij in zijn paleis huisvestte] in die paradijselijke tuin... Daarvoor gaf hij hun opium en zodra zij de opium tot zich hadden genomen vielen zij onmiddellijk als half verlamd in slaap en sliepen dan wel drie dagen en nachten. Terwijl ze sliepen bracht hij hen naar zijn tuin en plaatste ze in verschillende kamers van de genoemde paleizen en daar werden ze wakker en merkten ze dat ze in het 'paradijs' waren... Op deze manier had hij al zijn volgelingen bezield met de wens om te sterven, dat wanneer de Oude Man hen beval zich op te offeren voor hem, ze zich gelukkig waanden, omdat ze hoopten naar het 'paradijs' te gaan. De volgelingen van de Oude Man doodden daarom heren en vele anderen, zoals vijanden van de genoemde Oude Man.

Op deze manier, door jongeren te drogeren en te verleiden met een prachtige tuin waarvan werd gedacht dat die het paradijs was, lukte het de Oude Man hen te overtuigen om aan zijn wil te voldoen: zijn vijanden te vermoorden.

De indrukwekkende snelheid waarmee Marco Polo's verhaal zich over Europa verspreidde, maakte het tot 'een van de meest gelezen en invloedrijkste, vertellingen in het laatmiddeleeuwse Europa. ${ }^{4}$ Mark Cruse, gespecialiseerd in middeleeuwse manuscripten, schrijft dat Polo's verslag zowel 'een reisverhaal is als een verhaal dat zelf een reis aflegde.. Misschien wel het meest noemenswaardige is dat er een exemplaar van Marco Polo's verslag meeging tijdens de reizen Christopher Columbus. ${ }^{6}$ Het beeld van de Oude Man en zijn Assassijnen dat Marco Polo schiep, bleef eeuwenlang het heersende verhaal en de aantrekkingskracht van die versie heeft tot op de 
Virani

dag van vandaag een grote invloed, zelfs op de wetenschap. Polo's jongere tijdgenoot, frater Odoric van Pordenone (overleden 1331), baseerde, hoewel hij de betreffende regio persoonlijk had bezocht, zijn verslag van de Oude Man van de berg bijna volledig op het verslag van zijn voorganger Marco Polo. ${ }^{7}$ Het verhaal van zijn reizen werd opgenomen in Het Boek der Wonderen (Le Livre des merveilles), een bijzonder rijkelijk geillustreerd vijftiende-eeuws manuscript dat nu in de Bibliothèque Nationale de France is ondergebracht. Figuur 2 is een miniatuur uit Odoric's dagboek met een illustratie van 'De Oude Man van de berg en zijn paradijs', compleet met fantastische centauren, vliegende harpijachtige wezens en dansende jonkvrouwen. ${ }^{8}$

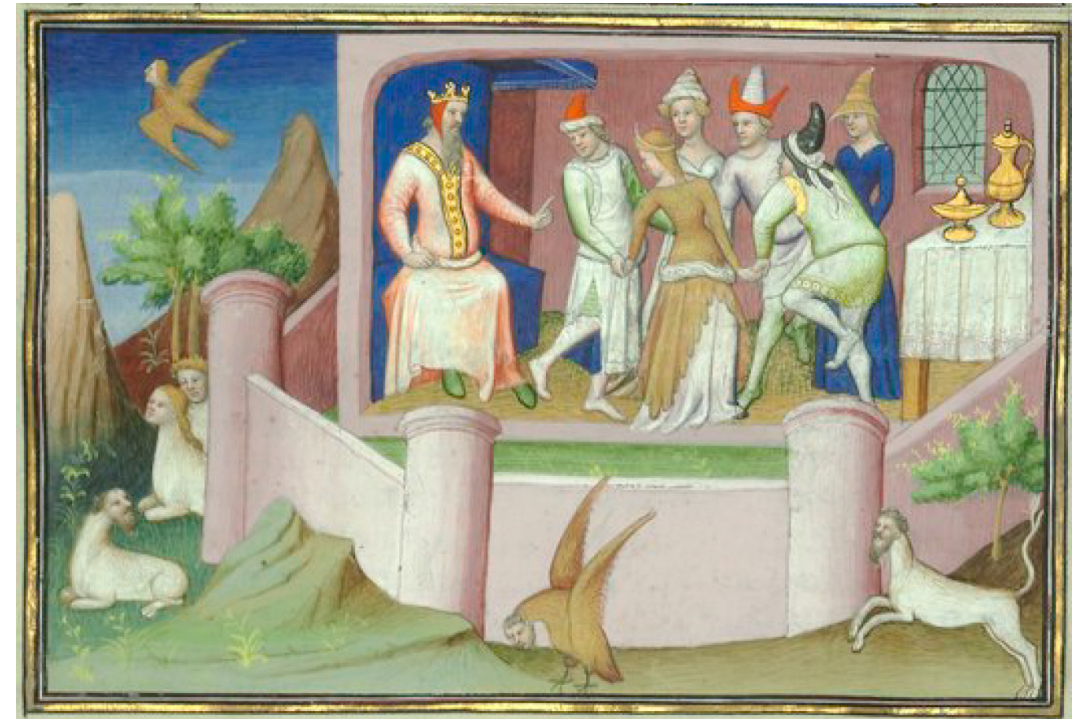

Figuur 2. De Oude Man van de berg en zijn paradijs.

Marco Polo zelf benadrukt de betrouwbaarheid van zijn boek. Hoewel hij toegeeft dat naast zijn eigen ooggetuigenverslagen er ook verhalen uit tweede hand zijn gebruikt en 'gehoorde dingen' bevat, maakt hij duidelijk dat hij:

het hoorde van mensen die geschikt waren om geciteerd te worden...alleen zij werden geciteerd zodat het boek juist en waarheidsgetrouw kon worden bevonden, zonder dat de dingen die gezegd werden als fabels weggezet konden worden. Zodat iedereen die dit boek leest of ervan hoort, het volledig moet geloven, omdat niets dichterbij de waarheid reikt... 
De moderne wetenschap heeft echter nieuwe ontdekkingen gedaan, die aanzienlijk afwijken van het beeld dat Marco Polo schetst, terwijl ze ook alle verslagen blootleggen die uitmondden in het zojuist besproken invloedrijke verhaal. ${ }^{10}$ De Oude Man, bekend als 'Alaodin', was niemand minder dan 'Ala'oed-din Muhammad (overleden 1255), de imam van ismailieten, die vanuit de staat Alamoet Perzië regeerde. De benamingen 'Assassijn', 'Mulecte' en andere varianten waren scheldwoorden afgeleid van Arabische woorden zoals hashish (mv., hashishin) en mulhid (mv., malahida), grofweg 'junks' en 'ketters. ${ }^{11}$ Hoewel ismailieten veelal in staat waren om in vrede te leven met hun soennitische buren, grepen tegenstanders, zoals de Seltsjoek-vizier Nizam al-Mulk (overleden 1092) en de Mongoolse historicus 'Ata-Malik Juwayni (overleden 1283) elke mogelijkheid aan om de reputatie van de ismailieten te schaden. Ondanks hun bekendheid met, en tegelijkertijd minachting van, de ismaillieten, hebben de moslimpolemisten niets vastgelegd dat enigszins in de buurt komt van de fantasierijke verhandelingen uit middeleeuwse Europese bronnen.

In dit artikel volgen we in het kort de geschiedenis van het zogenaamde 'geheime genootschap' van nizari ismailieten en onderzoeken we hoe Marco's Polo verhalen van de ismailieten nog steeds een krachtige invloed uitoefenen op ons historisch begrip van hen. Ten slotte zullen er een aantal zeldzame bronnen worden behandeld, waarvan vele onlangs ontdekt zijn, die het echte verhaal van de nizari ismailieten pogen te vertellen, dat, hoewel minder fantastisch dan dat van Marco Polo, even betoverend is.

\section{Een verhaal op aller lippen: de historische achtergrond van de Nizari Ismaïlieten}

$\mathrm{Na}$ de dood van de profeet Mohammed ontstonden er verschillende interpretaties van zijn boodschap in de moslimgemeenschap. Zo erkende de imami shi'ah stroming de bevoorrechte positie van de afstammelingen van de profeet Mohammed, en steunde zij deze imams trouw in hun leiderschap. $\mathrm{Na}$ de dood van Imam Jafar al-Sadiq in 765 raakte de gemeenschap verdeeld. Door verschillende groeperingen werd uiteindelijk het religieus leiderschap aan zijn zoon Moesa al-Kazim toegekend, terwijl andere vasthielden aan zijn oudste zoon, Isma'il al-Mubarak. Op den duur werden de aanhangers van Moesa al-Kazim bekend onder de naam Ithnaasharis, of, na de verdwijning van hun twaalfde imam, twaalver sjiieten. De aanhangers van Isma'il al-Mubarak werden aangeduid als Ismaïlieten. Tegenwoordig vormen 
Virani

de twaalvers de meerderheid van de bevolking in landen als Iran, Irak, Azerbeidzjan en Bahrein. Terwijl de ismailieten, geleid door hun Imam Aga Khan IV, als kleine groeperingen verspreid zijn over verschillende landen in de moslimwereld. De ismailieten, samen met vele andere sjiieten, verdedigden de rol van het verstand en bezinning in hun religie en zij verloochenden uitsluitend letterlijke interpretaties van het Schrift. Ze werden aldus de mensen van de innerlijkheid (batin) genoemd, met daartegenover de uiterlijkheid (zahir).

In het jaar 909 vestigde de Isma'ili Imam 'Abd Allah al-Mahdi (overleden 934) het Fatimidische kalifaat. Op het hoogtepunt van hun macht regeerden de Fatimidische kaliefen over een groot deel van Noord-Afrika, het Arabisch schiereiland, de Levant en Sicilië. Bovendien steunden zij tijdens hun heerschappij talrijke wetenschappelijke en literaire ondernemingen.

Het politieke succes van de Shi'i Fatimiden alarmeerde hun rivalen, en de soennitische Abbasiden reageerden dan ook heftig, met tal van lasterlijke polemische werken. De paniek die werd veroorzaakt door de triomfen van de ismailieten kan worden afgeleid uit de toon van sommige beschuldigingen die tegen hen waren gericht. De theoloog al-Baghdadi (gestorven 1037) legt hen bijvoorbeeld ten laste:

Het kwaad dat door de Mensen van Innerlijkheid [ismailieten], de islamitische sekten is aangedaan is groter dan het kwaad aangedaan door de joden, christenen en magiërs; ja, ernstiger dan de verwonding die de materialisten en andere niet-gelovige sekten hen hebben aangedaan; ja, ernstiger dan de verwonding die ze hebben opgelopen van de Antichrist [Dajjal] die aan het einde der tijden zal verschijnen. Want degenen die, als gevolg van de zendingsactiviteiten van de Mensen van Innerlijkheid, op een dwaalspoor zijn gebracht, sinds het begin van de missie tot op de dag van vandaag, zijn talrijker dan degenen die op een dwaalspoor worden gebracht door de Antichrist wanneer hij verschijnt, omdat de duur van de opruiing van de Antichrist niet langer zal zijn dan veertig dagen. De ondeugden van het Volk van Innerlijkheid zijn talrijker dan zandkorrels of regendruppels. ${ }^{12}$

$\mathrm{Na}$ de dood van Imam al-Mustansir in 1094 volgde er een opvolgingsstrijd tussen twee van zijn zonen, Abu Mansur Nizar en al-Musta'li Bi'llah. Kort voor deze breuk had Hasan-i Sabbah, een van de meest prominente hoogwaardigheidsbekleders van al-Mustansir, met succes het fort van Alamoet veroverd, dat het hoofdkwartier van de nizari ismailieten zou worden. Onder het kundige leiderschap van Hasan en zijn opvolgers verspreidde het ismailisme zich over de gebieden van zijn gezworen vijanden:

462 
de Turkse seltsjoeken. De seltsjoeken regeerden met de zegening van de Abbasidische kaliefen, die onderhand grotendeels waren gereduceerd tot slechts titulaire leiders van de soennitische islam. Sjiitisch ismailitische gemeenschappen, die op het grondgebied van de seltsjoeken woonden, hadden te maken met veelvuldige bloedbaden, levende verbrandingen en liepen het risico aan het zwaard geregen te worden in Aleppo, Damascus, Qazwin, Isfahan, Zuid-Khorasan en elders. Maar doordat de Ismailieten zich vestigden binnen een aantal verschillende forten werden zulke acties moeilijker gemaakt. Hoewel ze niet in staat waren om de overweldigende militaire superioriteit van het Seltsjoek Rijk te overmeesteren, slaagden de ismailieten er desalniettemin in zichzelf te verdedigen. Dit deden ze door hun tegenstanders, die de massamoorden tegen hen leidden of aanmoedigden, te identificeren en te vermoorden. Hun combinatie van zowel verspreiding, infiltratie als moord leverde verbluffende resultaten op.

Volgens Ibn al-Athir, wiens werk wordt beschouwd als het toppunt van islamitische historische annalen, waren zoveel van de hovelingen en soldaten van sultan Barkiyaruq (overleden in 1105) Ismaïlieten geworden, dat sommige van zijn officieren toestemming hadden gevraagd om in het harnas voor hem te verschijnen opdat zij niet aangevallen werden, zelfs in het bijzijn van de sultan. ${ }^{13}$

Ondanks het vijandige klimaat van destijds, lijkt het erop dat de literaire productie van de Nizari van Alamoet aanzienlijk is geweest. Zelfs hun meest verstokte tegenstanders gaven toe dat de bibliotheek van Alamoet beroemd was om zijn collectie. ${ }^{14}$ Toch heeft slechts een handvol uitgaven van de ismaili uit deze periode het overleefd, wat zeker een van de redenen is dat verslagen als die van Marco Polo zo lang in zwang zijn geweest. Een recent ontdekte eigentijdse ismaili-bron, betreffende De Erkenning van God, geeft ons echter inzicht in wat de gemeenschap in Alamoet zoal bewoog. De grondgedachte van de tekst is dat het doel van de schepping de mensheid zelf is, maar dat het menselijke bestaan an sich betekenisloos is tenzij mensen zichzelf wijden aan het zoeken en erkennen van God. Van alle schepsels op aarde hebben alleen menselijke wezens de aanleg om gnosis van hun Schepper te verkrijgen. ${ }^{15}$ Een andere recent ontdekte bron, de Prins van Sistan, benadrukt: 'Het basisprincipe van religie is het erkennen van God, terwijl hoe Hij wordt aanbeden een afgeleide tak is. ${ }^{36}$ Zulke sentimenten zijn eeuwenlang invloedrijk gebleven in de Ismailitische geschiedenis en tot op de dag van vandaag overheersend.

Ondanks de wrede daden van de Seltsjoeken jegens de ismaïlieten van 
Virani

Alamoet verscheen er een tegenstander met een veel grotere stootkracht aan de horizon: de Mongolen. Een onheilspellende aankondiging van de aanstaande massamoord wordt gedaan door Willem van Rubroeck, een Franciscaanse kloosterbroeder aan het hof van koning Lodewijk IX van Frankrijk, die op een diplomatieke missie was gestuurd naar de Grote Khan Mongke. Hij vertelt dat de Grote Khan zijn broeder Hulagu naar het grondgebied van de ismailis had gestuurd met een leger, 'en hij beval hem om ze allemaal ter dood te brengen.' Toen de vesting van Alamoet in werd genomen door de Mongolen in 1256, vroeg 'Ata-Malik Juwayni, assistent en historicus van Hulagu, toestemming om de vermaarde bibliotheek te bezoeken. Daar vond hij een groot aantal boeken over de religie van de ismailis, die hij vervolgens veroordeelde tot de brandstapel, waarbij hij slechts kopieën van de Koran en een paar andere verhandelingen ongeschonden liet. ${ }^{18}$ De ismaïlis waren een vergelijkbaar lot beschoren als hun boeken, en werden lukraak opgejaagd en afgemaakt. Juwayni schreef: '[De imam] en zijn volgelingen werden tot moes geslagen en daarna aan het zwaard geregen; en van hem en zijn volgelingen was geen spoor achtergelaten, en hij en zijn verwanten werden niets dan een verhaal op aller lippen en een traditie in de wereld.' ${ }^{19}$ Het Virginia Museum of Fine Arts heeft een schilderij in haar collectie dat de beroemde kunstenaar Basawan heeft gemaakt

voor keizer Akbar van Figuur 3. De Mongolen valen Alamoet aan.

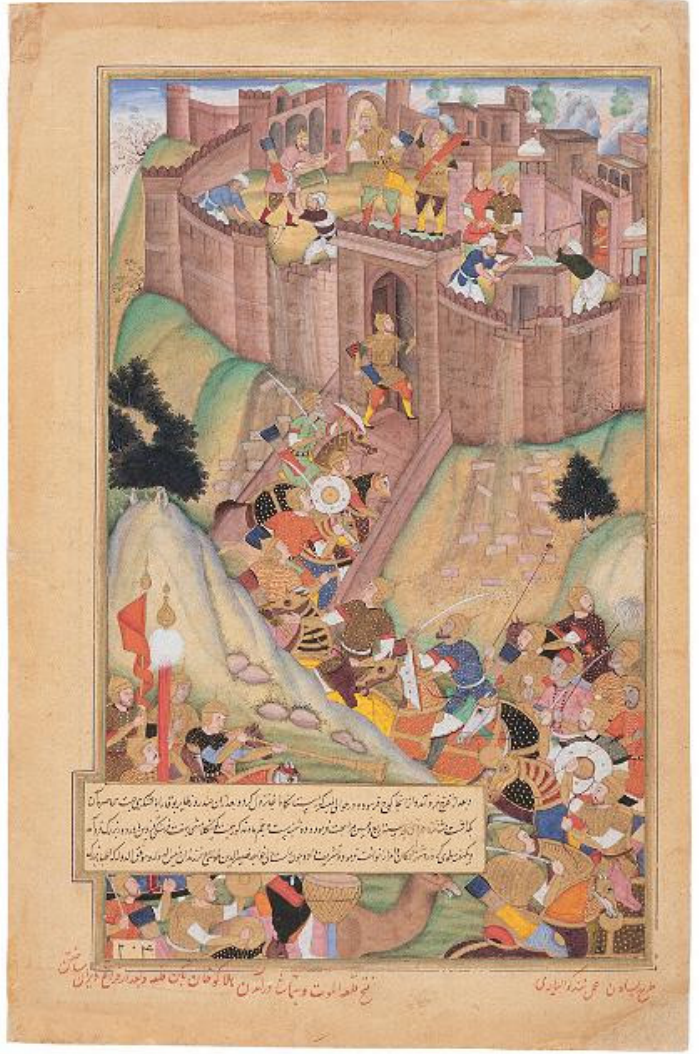

\section{4}


India (overleden 1605), waarop de menigte Mongolen die Alamoet had aangevallen wordt afgebeeld (figuur 3). De bijgeleverde tekst vertelt ons dat Hulagu Khan, kleinzoon van Genghis Khan, 'omhoog ging om Alamoet te bekijken, en door de grootsheid van de berg, verbijsterd, zijn vinger van verbazing tussen zijn tanden stak!' Voortaan zou het lijken alsof de Ismaïlieten simpelweg opgehouden waren te bestaan, verdwenen uit de geschiedenisboeken, maar zoals we hebben gezien, niet verdwenen uit de fantasie.

\section{Een tekst met een bijna mythische zeggingskracht: van Marco Polo tot de moderne wetenschap}

In het artikel 'An Early Moment in the Discourse of 'Terrorism': Reflections on a Tale from Marco Polo' onderzoekt Bruce Lincoln de stereotiepe, sterke, maar ook zeer gekleurde invloed van Marco Polo's beschrijving van de 'Oude Man van de Berg', een tekst met een welhaast mythische zeggingskracht. ${ }^{20}$ De tekst brengt de mensheid op basis van religieuze gronden onder in drie categorieën: als christenen, 'afgodendienaren' (oftewel boeddhisten en andere gelovigen die niet genoemd worden) en 'Saracenen', ofwel moslims. Elk van de drie gemeenschappen wordt door de auteur een leider toegewezen - de legendarische Pape Jan voor de christenen, de Grote Khan voor de 'afgodendienaren' en de Oude Man van de Berg voor de moslims. ${ }^{21}$ Hierin verschilde Marco Polo van eerdere christelijke verslagen, die de ismailieten als een minderheidsgemeenschap binnen de islam erkenden:

Oude verslagen van de Assassijnen lieten de Oude Man als religieus leider zien die op het dwalende af was. Hij zette zich in voor een, in zijn ogen, heilige opdracht en ronselde en trainde andere gelovigen die hij te goeder zo niet te kwader trouw een hemelse beloning beloofde. Polo's tekst daarentegen voegde seks, drugs en illusie toe aan de mythe van het paradijs der Assassijnen waarbij hij de Oude Man als cynisch sekteleider neerzette, een duivel in een oosters verhaal en een gewetenloze moordenaar. ${ }^{22}$

Daarmee lijken de dwalingen van de Oude Man en zijn discipelen, zoals in de versie van Marco Polo staan beschreven, typerend te zijn voor de islam. Op veel manieren bleef Marco Polo's De wonderen van de Oriënt (1298), die was geschreven tijdens de nasleep van de christelijke kruistochten, de islam afbeelden op manieren die gebruikelijk waren in Europa. Richard Southern beschrijft in Westerse opvattingen over de islam 
Virani

in de Middeleeuwen (Western Views of Islam in the Middle Ages, 1978) in een hoofdstuk met de sprekende titel 'Het Tijdperk van Onwetendheid (The Age of Ignorance)', twaalfde-eeuwse auteurs als mensen die zich "laafden aan triomfantelijke onwetendheid." ${ }^{23}$ Het elfde/twaalfde-eeuwse Roelantslied beschrijft de islamitische 'Saracenen', in werkelijkheid strikte monotheïsten, als polytheïsten en afgodendienaars die een onheilige drie-eenheid van Apollin, Termagant en Mahomet (Mohammed) aanbeden. De Legenda aurea, een invloedrijke hagiografie samengesteld rond 1260, verbeeldt een leugenachtige Mohammed die een duif aanleert om graan uit zijn oor te eten zodat zijn goedgelovige volgelingen dachten dat die de aartsengel Gabriël was. Dan was er ook nog eens Marco Polo's landgenoot Dante (overleden 1321) die in De goddelijke komedie, Mohammed en zijn bloedverwant Ali ibn Aboe Talib, door Dante minachtend de 'verraderlijke Assassijn' genoemd, verdoemde naar de krochten van de hel. ${ }^{24}$

Tegelijkertijd begonnen enkele Europeanen met een meer serieuze bestudering van de islam, gebaseerd op originele bronnen, alhoewel nog dikwijls met twist of bekering als doel. De vertaling van de Koran in het Latijn door Robert van Ketton uit 1143 was dan weer een grote stap vooruit in de ontwikkeling van een genuanceerder begrip ervan. ${ }^{25}$ Later pleitten figuren als Raymond Lull (overleden 1315) voor het sturen van zendelingen en het bekeren van moslims, in plaats van kruistochten te organiseren. Voor iets dergelijks als het sturen van zendelingen was een grondige bestudering van oriëntaalse talen nodig. ${ }^{26}$ Zulke personen waren echter buitengewoon zeldzaam. We weten bijvoorbeeld dat er in de dertiende en veertiende eeuw slechts zeventien zendelingen waren die enige vaardigheid in het Arabisch bezaten. ${ }^{27}$ Genuanceerdere studies van de islam die gedaan werden in het westen zijn waarschijnlijk afkomstig van Guillaume Postel (overleden 1581), die halverwege de zestiende eeuw Arabisch doceerde aan het Collège Royal te Parijs. ${ }^{28}$ Hoewel hij meer sympathie had voor het jodendom en de islam dan sommige anderen, betoogde hij desondanks dat de islam een goddelijke straf was voor de verdeeldheid onder de christenen. Toch werd er in 1613 een leerstoel Arabisch opgericht in Leiden, gevolgd door één in Cambridge in 1633 en één in Oxford drie jaar later.

Gezien de geringe bekendheid van de islam in het westen, is het geen verrassing dat destijds vrijwel niemand afwist van het sjiisme. Hoewel er enorme vooruitgang is geboekt in eigentijds onderzoek is deze niet doorgedrongen tot andere kringen, specialisten uitgezonderd. De meest recente Engelse vertaling van Marco Polo's Le Devisement du monde is 
hiervan een sprekend voorbeeld. Hoewel geprezen door critici, citeert de vertaler het vroegveertiende-eeuwse werk van John de Joinville, die stelde dat de Oude Man 'niet een volger van Mahomet was, maar de wetten van 'Ali voorstond.' De vertaler achtte het noodzakelijk om te noemen dat de auteur 'Ali verkeerd identificeerde als Mohammeds oom, in plaats van zijn neef en zwager. In dezelfde editie wordt verbazingwekkend genoeg niet de gangbare misvatting aangekaart die de sjiieten als volgelingen van 'Ali, in plaats van Mohammed', zag. ${ }^{29}$

Met betrekking tot de ismailis van Alamoet in het bijzonder, publiceerde de Oostenrijkse oriëntalist Joseph von Hammer-Purgstall (overleden 1856) een verhandeling die in zijn geheel het narratief van Marco Polo overnam, en daarmee de minachtende benaming 'Assassijn' populariseerde. Dit bracht een wetenschappelijk vernis aan de legenden die in omloop waren sinds de tijd van de kruistochten. ${ }^{30}$ De spottende term was dermate ingeworteld dat zelfs een ruimdenkend geleerde als Marshall Hodgson (overleden 1968) zijn dissertatie de titel De Orde van de Assassijnen: de strijd van de vroege Nizari ismailieten tegen de islamitische wereld (The Order of Assassins: The Struggle of the Early Nizari Isma'ilis against the Islamic World) gaf. ${ }^{31}$ Bernard Lewis (overleden 2018) gebruikte ook regelmatig de gehate term, met als bekendste voorbeeld de titel van zijn monografie, De Assassijnen: een radicale sekte in de islam (The Assassins: A Radical Sect in Islam). ${ }^{32}$ Terwijl de specialistische wetenschap nu grotendeels het gebruik van de middeleeuwse term voor deze moslimminderheid heeft laten vallen, is deze elders nog steeds gangbaar, zelfs binnen de academische wereld.

Ondertussen werden in populaire verhalen en literatuur de ismaïlieten fida'is of toegewijden als helden gezien. ${ }^{33}$ In de Arabische tekst Het leven van al-Zahir Baibars worden ze bijvoorbeeld afgeschilderd als zeer krachtige figuren - koene ridders, onsterfelijke krijgers, avontuurlijke bergbewoners die sterk vasthouden aan hun onafhankelijkheid en wars zijn van externe invloed en autoriteit. ${ }^{34}$ Deze romantische beschrijving is ook te vinden in ismailifolklore; als het gaat over de Mammelukken is al hun hoffelijkheid ontdaan van expliciete religieuze connecties. ${ }^{35}$ Ze verschijnen niet als verachtelijke ketters maar in plaats daarvan als de Banu Isma'il, een familie die afstamt van de dappere Ali. Erfgenamen van zijn legendarische moed en kracht, zijn feilloze rechtvaardigheid en zijn onverschrokkenheid. Zelfs de vrouwelijke leden van de Banu Isma'il zouden eenzelfde heldenmoed bezitten. Zo gaat bijvoorbeeld het verhaal over de stoutmoedige Shamsa, die zich voordoet als Byzantijnse graaf en zo opdrachten vervult voor een 
Virani

geheim agent die door de Sultan Baybars naar Keizer Michael is gestuurd. De Banu Isma'il wordt vaak speciale missies toegewezen, zoals het redden van de islamitische gevangenen van Yanisa, of zelfs het bevrijden van Baybars zelf wanneer hij gevangen wordt genomen door Genuese piraten.

De met tegenzin toegegeven waardering van sommige islamitische schrijvers, voor wat zij zagen als het doorzettingsvermogen van de Ismailieten in onwaarschijnlijke omstandigheden, wordt ook weerspiegeld in sommige invloedrijke Westerse verbeeldingen. Zo vergeleken Provençaalse dichters de romantische devotie aan hun geliefden met de loyaliteit van de fida'is aan hun leider. ${ }^{36}$ Het meest bekende Sloveense literaire werk ooit is de roman Alamoet (1938) van Vladimir Bartol (overleden 1967), die behoorde tot de Sloveense minderheid in Italie. ${ }^{37}$ Literaire critici zagen het werk van Bartol als een allegorie van de eigentijdse revolutionaire organisatie TIGR die streed tegen het fascistische regime van Benito Mussolini, waarin Slovenen en Kroaten geconfronteerd werden met een gedwongen Italianisering. Simona Škrabec schreef: 'Het beeld van de bergbeklimmers bereid om te sterven op een onherbergzame rots is als de onbevreesde strijd tegen buitenlandse onderdrukking. Het verlangen naar macht is in de roman van Bartol een radicale wens om het bestaan van een volk en hun vrijheid veilig te stellen.' ${ }^{38}$ Filosoof Mirt Komel constateert in een onderzoek naar de verbeelding van 'Assasijnen' in fictieve voorstellingen sinds de verschijning van Bartols Alamoet 'het weer oosters maken van de Assassijnen dat het traditionele beeld grotendeels verandert is dat de romans de Assassijnen aan de ene kant als voorlopers van het moderne islamitische fundamentalisme en terrorisme laten zien terwijl ze aan de andere kant de Assassijnen geleidelijk van de oosterse schurk omtoveren tot westerse held. ${ }^{39}$ Bartols roman heeft niet alleen de Sloveense componist Jarc Matjaz geïnspireerd tot het schrijven van de opera Alamoet, maar ook Assassin's Creed, één van de grootste videogamefranchises ooit, die niet alleen miljarden dollars heeft opgeleverd, maar ook een stripboek, roman, en zelfs een film teweeg bracht. ${ }^{40}$ De Disney film Prince of Persia: The Sands of Time is eveneens deels gebaseerd op de denkbeeldige verhalen van Alamoet, en François Barangers artistieke verbeelding van het ismailikasteel roept eveneens een Marco Polo-achtige mystiek op (figuur 4). 


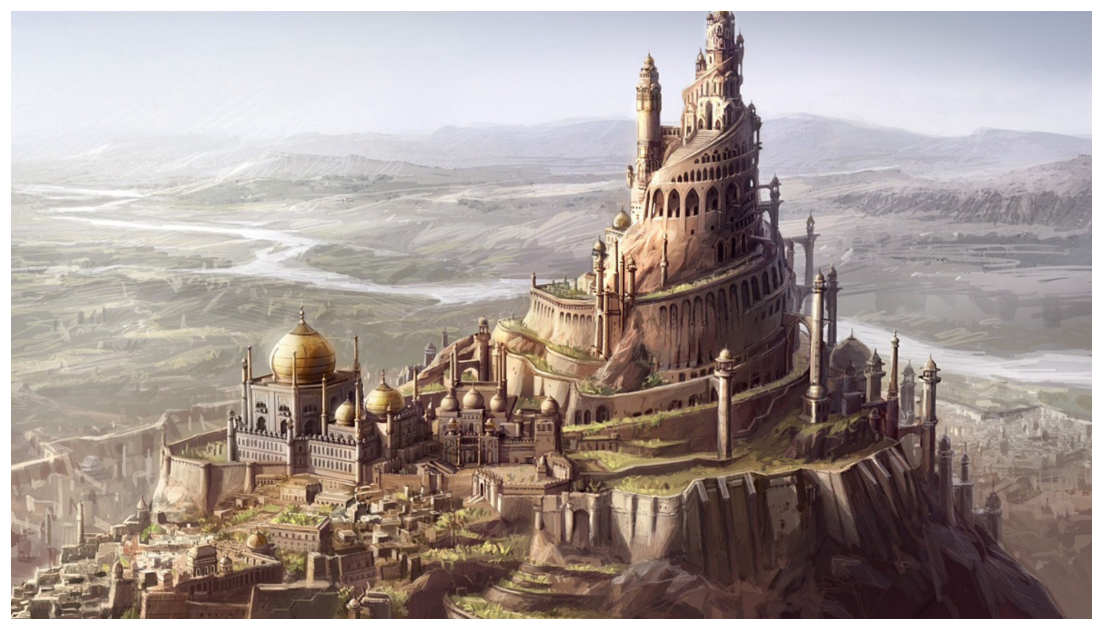

Figuur 4. François Barangers afbeelding van Alamoet voor de Disney Film Prince of Persia.

\section{In hun eigen woorden...}

De verwoestingen door de Mongolen en het verbranden van de grote ismailibibliotheek van Alamoet, sluit alle hoop op het volledig kunnen begrijpen van hoe deze gemeenschap zichzelf en de wereld om zich heen zag uit. ${ }^{41}$ Recente ontdekkingen hebben echter de mogelijkheid gegeven een aantal waardevolle inzichten te verkrijgen. Originele werken uit de Alamoet periode, waarvan sommige voor het eerst in dit artikel vertaald zijn, geven ons een heel ander beeld van de Ismailigeschiedenis dan Marco Polo indertijd heeft gedaan.

Een van de oudste beschikbare bronnen om de ismailieten te begrijpen is het Boek van Belijdenis en Credo van Shahrastani (overleden 1153). Shahrastani wordt beschreven als 'misschien wel de grootste vroegmoderne historicus van religies. ${ }^{42}$ Lang werd gedacht dat hij een soenniet was, maar recent onderzoek heeft aangetoond dat Shahrastani er ismaili-sjiitische denkbeelden op nahield. In het Boek van Belijdenis en Credo werd getracht de verschillende religieuze overtuigingen van alle mensen in de 'bekende wereld' op een zo gelijk mogelijke voet te benaderen. In veel opzichten reflecteert Shahrastani de belangen van eerdere ismaili-auteurs, zoals de Broeders van Kuisheid (actief in de 10e-11e eeuw) en Kirmani (overleden na 1020) in hun geloof in de religieuze erfenis van de mensheid. Zo citeerde 
Virani

Kirmani letterlijk uit pre-islamitische geschriften in zijn werk, maar ook uit de Hebreeuwse Torah en de Syrische Gospels. Dit was zeer ongebruikelijk voor zijn tijd. ${ }^{43}$ In recente jaren is in Turkije een zeldzaam en kostbaar manuscript gevonden dat in Alamoet is vervaardigd. Het bevat een Perzische vertaling van Shahrastani's werk. ${ }^{44}$ De tekst begint met:

Ere zij God, de lof die alle dankbare lieden verschuldigd zijn, een volkomenheid aan lof voor al Zijn gunsten: een overvloedige lof, oprecht en zalig. Moge de zegen van God op Mohammed rusten, de uitverkorene, de apostel van genade en de bezegeling van de profeten; en op zijn nakomelingen die goed en zuiver zijn: een zegen die voortduurt tot de Dag des Oordeels, zoals de zegen geschonken aan Abraham en zijn nakomelingen. Ja zeker, God is het meest waardig om te danken en te eren.

Toen God mij de machtigheid gaf om de religieuze overtuigingen van andere volkeren te bestuderen (zowel degenen die tot verschillende religies en gemeenschappen behoren als degenen die andere overtuigingen en geloofsbelijdenissen volgen), om ook hun bronnen te bestuderen en het bekende en onbekende uit te zoeken, besloot ik om al deze informatie samen te voegen in een kort compendium bestaande uit alle religieuze overtuigingen en geloofsbelijdenissen van andere volkeren, om in een les te voorzien voor diegenen die kunnen reflecteren en als middel voor reflectie voor diegenen die er een les uit kunnen leren. ${ }^{45}$

Deze nieuwsgierigheid van de ismailieten naar verschillende religies en hun manieren om tot God te komen, komt later terug in het meest belangrijke en nog intacte compendium van de ismaili van Alamoet, het Paradijs van Overgave van Hasan-i Mahmoed (overleden 1243) en Nasiroed-din Tusi (overleden 1274). Hierin staat: 'God Almachtig kan niet worden aangesproken met één naam, maar met een veelvoud aan namen. De Perzen noemen Hem 'Khuda,' de Arabieren 'Allah,' de Turken 'Tengri,' de Franken 'Dieu, de Indiërs 'Hari Narayan,' de filosofen 'het Noodzakelijk Bestaande,' enzovoort. ${ }^{46}$ Een tijdgenoot van Shahrastani was de eerder genoemde Qasum Tushtari (overleden in de 12e eeuw). Zijn recent herontdekte de Erkenning van God dateert uit de vroege periode van de geschiedenis van Alamoet, en zegt ons dat het ultieme doel in een mensenleven het kennen van God is. Hij benadrukt dat de weg naar deze kennis via de profeten en imams loopt. Inderdaad, dit streven is ook wat de nakomelingen van Adam onderscheidt van dieren. Om deze reden heeft God de profeten (de Sprekers van de goddelijke bedelingen) en de imams (de Bewijzen van spirituele echtheid ) 
afgezonden naar de mensheid. Aldus, zo schrijft Tushtari:

De gemeenschap van verdedigers en vrienden van het geloof, de naar zekerheid zoekenden en de aanbidders van de Goede en Zuivere Familie van de Profeet Mohammed (moge God hen immer behoeden) moeten weten dat het voor de ingewijden en religieuzen zo klaar als een klontje is dat de stoffelijke wereld geschapen is voor de mensheid. Het doel van de mensheid is God te erkennen (Hij zij geprezen) zodat de betekenis van "Wij louterden Adams kinderen" (Koran, 17:70), niet zuiver latent is maar zich manifesteert in de mensen zelf. Door de eeuwen heen is dit en zal dit de ordonnantie van de Verkondigers van het goddelijke woord, de Profeten zijn en van de Volgelingen der Profeten die de mensheid tot verlossing leiden (mogen zij rusten in vrede). ${ }^{47}$

Degenen die wilden beginnen aan deze zoektocht om dichterbij God te komen werden uitgekozen door ismaili-missionarissen, 'uitnodigers' (da'is) genoemd. Protocol en Invitatie voor Godgelovigen, toegeschreven aan Shamsoed-din at-Tayyibi van Syrië (overleden 1254), biedt richtlijnen voor diegenen die zich wilden bekeren tot de ismaili. De tekst wordt doorgaans geassocieerd met het religieus leiderschap van 'Alàoed-din Muhammad, dezelfde imam die door Marco Polo de Oude Man van de Berg werd genoemd. De kwaliteiten die verwacht werden van degenen die Ismaïlis wilden worden, zijn als volgt beschreven :

[De ingewijde] moet een mooi karakter hebben, gesluierd in bescheidenheid; hij moet vechtlustig noch strijdlustig zijn; noch moet hij slecht spreken over anderen noch oneerbiedig zijn. Hij moet niet laf, gulzig of gierig zijn. Hij moet vasthouden aan de religieuze geboden en de hemelse bedelingen van Mohammed en de goddelijke wetten aanbidden. Hij moet waarde hechten aan kennis en wijsheid, en zich keren tegen diegene die vijandigheid toont jegens de geboden en verboden van de hemelse bedelingen. Hij moet deugdzame en godsdienstige mensen benaderen en tot zijn vrienden rekenen terwijl hij de corrupten, onwetenden en hypocrieten moet vermijden. Als hij deze kwaliteiten bezit, dan is hij oprecht in zijn zoektocht en verlangen om gnosis te verkrijgen, en zuiver in zijn verlangen en discipline. Zo zou hij toelating in de gemeenschap verdienen en zou het hem toegestaan zijn om de eed van trouw af te leggen. ${ }^{48}$

Een van die zoekers die zich bij de Ismaillieten wilde aansluiten en de eed van trouw heeft afgelegd aan de imam was de eerder genoemde Nasiroed-din 
Virani

Tusi. Hij werd gezien als een van de meest vooraanstaande wetenschappers en filosofen van de moslimwereld. Tusi bekeerde zich op een zeker punt in zijn leven tot het ismaillisme. Zijn spirituele autobiografie, De Reis, verklaart zijn motivering voor deze keuze. ${ }^{49}$ De aantrekkingskracht van dit geloof betrof onder andere de nadruk op 'kennis en intellect.' In het hoofdstuk met deze naam, in een boek waar hij samen met zijn mentor Nasiroed-din Muhtasham (overleden 1257) aan werkte, wordt een Profetische traditie aangehaald, 'Het eerste ding dat God creëerde was het intellect. Hij zei ertegen, 'kom nabij,' en het kwam dichterbij. Hij zei, 'ga terug', en het trok zich terug. Toen zei hij, 'in mijn glorie en grootsheid, creëer ik niets dierbaarder aan mij dan jij! Door jou zal ik nemen, door jou zal ik geven, door jou zal ik straffen, en door jou zal ik belonen. ${ }^{50}$

Tusi schreef ongeveer 150 boeken in het Perzisch en Arabisch. Daarin heeft hij vele waardevolle bijdragen geleverd aan de wiskunde, astronomie en verscheidene andere onderwerpen. Zijn meest productieve jaren waren toen hij onder de hoede stond van ismaili-patroni. Een van zijn korte verhandelingen, de Gedragscode voor Gelovigen, is een compilatie van adviezen van imams en van andere leidende figuren binnen het ismailisme over hoe een goede Ismailli zich in religieuze zin dient op te stellen. Het gaat dan om voorschriften over de erkenning van en gehoorzaamheid aan de Imam, opvolger van de Profeet, de constante herinnering aan God, aanvaarding van het lot, zich overgeven aan Gods wil, onthechting van het wereldlijke leven, en toewijding aan het hiernamaals:

De gemeenschap die zoekt naar het ware geloof en zichzelf als ismaili beschouwt, moet de voorwaarden voor het zijn van een gelovige en een ismailli kennen. Zij die beweren dat ze ismaïlis zijn moeten drie eigenschappen hebben. Ten eerste moeten zij kunnen herkennen wie de Imam is van hun tijd, en moeten ze zich houden aan het bevel van de ware meester en God aanroepen. Het tweede is aanvaarding. Zij moeten zich overgeven aan welk goeds of slechts hen overkomt, hetzij zegen, hetzij tegenslag. Ten derde komt overgave, dit betekent volledige overgave aan God. Met andere woorden, alles dat ze niet meenemen naar de volgende wereld moet worden beschouwd als dingen die geleend worden, die teruggegeven moeten worden. Rijkdom, familiebanden en alle eigendommen van de wereld moeten worden gewijd aan de waarheid om de status van gelovigheid te bereiken. ${ }^{51}$

Volgens Tusi was de meest onderscheidende eigenschap van een ismaili om de imam van zijn tijd te erkennen en om zijn begeleiding en interpretatie van de boodschap van de Profeet te volgen. Dit komt terug in het gehele 
corpus van intact gebleven ismaïli werken uit Alamoet. Hoewel Marco Polo in zijn vertelling de diepe devotie van de ismailieten aan hun imam erkende, faalde hij in het begrijpen van de historische, filosofische en dogmatische redenen voor deze trouw. De Poezië over Herrijzenis en Verlichting, geschreven door Tusi's hechte vriend Hasan-i Mahmoed, bieden inzicht in de diepe liefde en verering van de vervolgde ismaïlieten voor de imam. In een gedicht vergelijkt hij de komst van Imam Hasan 'ala Dhikrihi's-salam, een van 'Ala'oed-dins voorgangers als 'de Oude Man van de Berg', met de komst van de lente. In gebieden onder Perzische invloed luidde het lentefestival Noroez een seizoen van vreugde in, een vruchtbare bodem voor de fantasie van creatieve zielen. De vergelijking van de lente met de aankomende verrijzenis in de Koran inspireerde ook veel dichters. Hasan-i Mahmoed vergeleek zo de komst van de imam met de verlevendiging van de aarde na de overheersing van de winter. Zoals moslims over de hele wereld in dezelfde richting bidden (qibla), zo was de imam het centrale punt voor de ware gelovigen. Net als het komen van dageraad na de nacht, net als een nachtegaal die het lied van Gods eenheid zingt en de mensheid aanspoort om het meesterschap van de Schepper te erkennen, voor de ismaïlieten was de imam:

Zoals het voorjaar, zoals de wereld van overvloed, zo kwam Hasan Zoals verborgen fortuin, zoals de 'qiblah' van het geloof, zo kwam Hasan

Zoals de bron van versiering, het universele goud Zoals bevalligheid, afstandelijkheid, zoals het begin van overvloed, zo kwam Hasan

Zoals de nachtegaal van Gods eenheid liefelijke melodietjes zingt In de rozenstruik in de tuin, zo kwam Hasan...

Voor het begin der tijd, leider achter de schermen $\mathrm{Na}$ het einde der tijd zelf heerser, zo kwam Hasan

Bron van het leidende licht van de grootste, machtigste God Glorie, glorie, o glorie, zo kwam Hasan ${ }^{52}$

\section{Slotwoord}

Het is een groot contrast tussen Marco Polo's versie van 'Er was eens een 
Virani

slechte prins...' en de documenten van Alamoet die recent zijn herontdekt door moderne wetenschappers. Verhalen over een ongure, geheime gemeenschap die eeuwenlang dominant was geweest, maken langzamerhand plaats voor een completer en meer genuanceerd beeld van het leven van een zeer intellectuele en spirituele gemeenschap, met een diepe devotie voor de Profeet Mohammed en zijn opvolgers. De ismaïlieten hadden veel gemeen met hun soennitische buren, maar waren in sommige dingen wezenlijk anders. Een van de meest belangrijke verschillen was de nadruk van de Ismailieten op het belang van een goede balans tussen de buitenkant, de fysieke, letterlijke en schijnbare vormen van de wereld en van het geloof, en hun innerlijke, spirituele, symbolische en intellectuele werkelijkheid. Zoals bevestigd wordt in de eerste ismailiproza na de val van Alamoet:

Deze gemeenschap heet de Mensen van Innerlijke Betekenis of Esoterieken (batiniyyah), want (we bevestigen dat) elke exoterische vorm een esoterische ziel en betekenis heeft. Die ziel is de bron van de exoterische vorm, terwijl de exoterische vorm de openbaring is van de esoterische ziel. Een exoterische vorm zonder esoterische ziel moet een hallucinatie zijn, terwijl een esoterische ziel zonder exoterische vorm een eenhoorn voor de reële wereld is. ${ }^{53}$

De ismaïlieten van Alamoet waren niet de hasjgebruikers die hun tegenstanders voorstelden. Ze waren daarentegen mensen die met trots de titel droegen die hun critici hen hadden gegeven: de Mensen van Innerlijke Betekenis (batiniyyah).

\section{Noten}

1. Dank is verschuldigd aan Zeinab Farokhi voor het invoeren van correcties in de tekst.

2. Marco Polo en Rustichello da Pisa, The Description of the World, ed. en trans. Arthur Christopher Moule en Paul Pelliot, 2 vols., Vol. 1 (Londen: George Routledge and Sons, 1938), 128. De citaten die volgen uit dit werk zijn alle ontleend aan deze vertaling, pagina 128-133, met enkele kleine wijzigingen. De originele versie van Marco Polo's verhalen, samengesteld in 1298, is verloren gegaan. Zijn verslag is bewaard gebleven in minstens 135 manuscripten in verschillende talen die vóór 1530 in Europa zijn gekopieerd. Tot op heden is Consuelo Wager Dutschke, "Francesco Pipino and the Manuscripts of Marco Polo's 'Travels"', de grondigste studie van het manuscripten corpus (PhD diss., University of California, Los Angeles, 1993). De Engelse vertaling 


\section{Een oude man, een tuin en een gezelschap van moordenaars}

die hier wordt gebruikt, is gebaseerd op een kritische editie, waarvan de vertaling varianten van verschillende vroege manuscripten tradities omvat, Polo en Rustichello, The Description of the World, vol. 1, 41.

3. De scène is afgebeeld in figuur 1, getekend door Signor Quinto Cenni naar een ruw ontwerp van Sir Henry Yule, Marco Polo, The Book of Ser Marco Polo the Venetian concerning the Kingdoms and Marvels of the East, ed. and trans. Henry Yule and Cordier Henri, 3rd ed., 2 vols., vol. 2 (London: John Murray, 1903), i, xvi.

4. Mark Cruse, "Marco Polo in Manuscript: The Travels of the Devisement du monde," Narrative Culture 2, no. 2 (2015): 171.

5. Ibid.

6. Nicolás Wey Gómez, The Tropics of Empire: Why Columbus Sailed South to the Indies (Cambridge, MA: MIT Press, 2008), 139-140; Folker Reichert, "Columbus und Marco Polo - Asien in Amerika: Zur Literaturgeschichte der Entdeckungen," Zeitschrift für Historische Forschung 15, no. 1 (1988): passim.

7. Odoric of Pordenone, The Journal of Friar Odoric in Contemporaries of Marco Polo: Consisting of the Travel Records to the Eastern Parts of the World of William of Rubruck (1253-1255), the Journey of John of Pian de Carpini (1245-1247), the Journal of Friar Odoric (1318-1330) and the Oriental Travels of Rabbi Benjamin of Tudela (1160-1173), ed. and trans. Manuel Komroff. New York, 1928, 246-247.

8. Le Livre des merveilles. Manuscript ark:/12148/btv1b52000858n, Bibliothèque nationale de France. Département des Manuscrits. Français 2810, Paris, 214r.

9. Polo en Rustichello da Pisa, The Description of the World, vol. 1, 73.

10. Farhad Daftary's nauwgezette onderzoek heeft de oorsprong van de Europese legendes van de Assassijnen getraceerd en geanalyseerd en Daftary heeft gekeken hoe ze het resultaat waren van complexe politieke en culturele krachten en structuren in de moslimwereld, die in de Europese narratieven van die tijd slecht begrepen werden. Dit artikel baseert zich ruimschoots op de bevindingen van Daftary in The Assassin Legends: Myths of the Ismailis (London: I.B. Tauris, 1994).

11. In 1809 was Silvestre de Sacy (overleden 1838) de eerste die de etymologie van de naam Assassijn realiseerde en documenteerde, en zijn bevindingen presenteerde aan het Institut de France op 7 juli 1809, "Mémoire sur la dynastie des Assassins et sur l'origine de leur nom," Annales des Voyages de la Geographie et de l'Histoire 8 (1809). Een verkorte versie van zijn argumenten is gepubliceerd in de Moniteurvan datzelfde jaar, "Mémoire sur la dynastie des Assassins et sur l'origine de leur nom," Moniteur 210 (July 29, 1809), net als een reactie op een kritiek op zijn proefschrift, ibid. 41. In dit verband, zie Georges Salmon, ed. Silvestre de Sacy (1758-1838), 2 vols., vol. 1 (Le Caire: Imprimerie de l'Institut français d’archéologie orientale, 1905), lxxiv. De eerste en de derde hiervan zijn in het Engels vertaald in noten D and $\mathrm{E}$ door Joseph Freiherr von Hammer-Purgstall, Die Geschichte der Assassinen, aus Morgenländischen Quellen, trans. Oswald Charles Wood, The History of the Assassins, derived from Oriental Sources (Londen: Smith en Elder, Cornhill, 1835); (oorspronkelijk gepubliceerd, Stuttgart: J.G. Cotta, 1818), 227-235 en 236-240. De Sacy breidde zijn argumenten uit in zijn "Mémoire sur la dynastie des Assassins," Mémoirs de l'Institut Royal de France 4 (1818). Deze uitgebreide versie is later in het Engels vertaald, "Mémoire sur 
Virani

la dynastie des Assassins et sur l'origine de leur nom," trans. Azizeh Azodi, "Memoir on the Dynasty of the Assassins and on the Etymology of their Name," in The Assassin Legends: Myths of the Isma 'ilis, ed. Farhad Daftary (Londen: I.B. Tauris, 1994).

12. Abū Man 'ūr 'Abd al-Qāhir ibn 'āhir al-Baghdādī, al-Farq bayna’l-firaq, ed. and trans. Kate Chambers Seelye, Moslem Schisms and Sects: (al-Far' bain al-fira ') being the history of the various philosophic systems developed in Islam (New York: AMS Press, 1966), part 2, 107-108.

13. 'Izz al-Dīn Ibn al-Athīr, al-Ta 'rīkh al-kāmil [a.k.a. al-Kāmil fî̀l-ta 'rīkh], 12 vols., vol. 10 (al-Qāhirah: Ma 'ba' at Mu 'ammad Mu' 'afā, 1303 AH/[1885 CE]), 112.

14. 'Alā' al-Dīn 'A 'à-Malik Juwaynī, Ta 'rīkh-i Jahāngushāy, red. Mu 'ammad ibn `Abd al-Wahhāb Qazwīnī, 3 delen, deel 3 (Leiden: E.J. Brill, 1912-1937), 269-270; Ta 'rīkh-i Jahāngushāy, vert. John Andrew Boyle, The History of the World-Conqueror, 2 delen, deel 2 (Cambridge, MA: Harvard University Press, 1958), 719.

15. Shafique N. Virani, "Persian Poetry, Sufism and Ismailism: The Testimony of Khwājah Qāsim Tushtarî’s Recognizing God," Journal of the Royal Asiatic Society Series 3, 29, no. 1 (January 2019): 24.

16. Ik ben momenteel bezig met het afronden van een kritische editie en vertaling van dit werk. Het meest grondige onderzoek tot op heden is Maryam Mu 'izzīi, "Bāznigarī dar rawābi' -i Ismā 'ìliyān wa mulūk-i Nīmrūz bar pāyah-yi matanī-yi naw yāftah," Mu 'àli 'àt-i ta 'rìkh-i Islām 2, no. 6 (Herfst 1389 HS/[2010 CE]).

17. Willem van Ruysbroeck (William of Rubruck), The Journey of William of Rubruck to the Eastern Parts of the World, 1253-55: As Narrated by Himself with Two Accounts of the Earlier Journey of John of Pian de Carpine, red. and vert. William Woodville Rockhill (Londen: Hakluyt Society, 1900), 222.

18. Juwaynī, Jahāngushāy, deel 3, 186-187, 269-270; Juwaynī, World-Conqueror, vol. 2, 666, 719.

19. Juwaynī, Jahāngushāy, deel 3, 277; Juwaynī, World-Conqueror, vol. 2, 724-725.

20. Bruce Lincoln, "An Early Moment in the Discourse of 'Terrorism:' Reflections on a Tale from Marco Polo," Comparative Studies in Society and History 48, no. 2 (2006): 242.

21. Ibid. 245.

22. Ibid. 253.

23. Richard William Southern, Western Views of Islam in the Middle Ages, 3de ed. (Cambridge: Harvard University Press, 1980); (Oorspronkelijk gepubliceerd. 1962), 28.

24. The Song of Roland, vert. William Stanley Merwin (New York: Modern Library, 2001); (Oorspronkelijk gepubliceerd, New York: Vintage Books, 1963), 104. Bellamy heeft het op zich genomen om de namen van de andere twee goden te ontcijferen in "Arabic Names in the Chanson De Roland: Saracen Gods, Frankish Swords, Roland's Horse, and the Olifant," Journal of the American Oriental Society 107, no. 2 (1987): 267-272. Stefano Mula, "Muhammad and the Saints: The History of the Prophet in the Golden Legend," Modern Philology 101, no. 2 (2003): 179, 185. Enkele unieke perspectieven op de bronnen voor Dantes verhaal aangaande de profeet Mohammed kunnen gevonden worden in Karla Mallette, "Muhammad in Hell," Dante Studies, 


\section{Een oude man, een tuin en een gezelschap van moordenaars}

with the Annual Report of the Dante Society, no. 125 (2007).

25. José Martínez Gázquez en Andrew Gray, “Translations of the Qur'an and Other Islamic Texts before Dante (Twelfth and Thirteenth Centuries)," Dante Studies, with the Annual Report of the Dante Society, no. 125 (2007): 80.

26. Róbert Simon, "Remarks on Ramon Lull's Relation to Islam," Acta Orientalia Academiae Scientiarum Hungaricae 51, no. 1 and 2 (1998): passim.

27. Barthold Altaner, "Zur Kenntniss des Arabischen im 13. und 14. Jahrhunderts," Orientalia Christiana Periodica 2 (1936): 440-448.

28. Brannon Wheeler, "Guillaume Postel and the Primordial Origins of the Middle East," Method \& Theory in the Study of Religion 25, no. 3 (2013): 247.

29. Marco Polo, Le Devisement du monde, trans. Sharon Kinoshita, The Description of the World (Cambridge: Hacket Publishing, 2016), 33-34 n41.

30. Joseph Freiherr von Hammer-Purgstall, Die Geschichte der Assassinen, aus Morgenländischen Quellen (Stuttgart and Tübingen: F.G. Cottaschen Buchhandlung, 1818); von Hammer-Purgstall, History of the Assassins.

31. Marshall G.S. Hodgson, The Order of Assassins: The Struggle of the Early Nizārī Ismā 'ìlīs against the Islamic World (New York: AMS Press, 1980); (Oorspronkelijk gepubliceerd, Den Haag: Mouton, 1955).

32. Bernard Lewis, The Assassins: A Radical Sect in Islam (London: Weidenfeld and Nicolson, 1967).

33. Voor meer hierover, zie Shafique N. Virani, The Ismailis in the Middle Ages: A History of Survival, A Search for Salvation (New York: Oxford University Press, 2007), 106.

34. Jean-Patrick Guillaume, "Les Ismaéliens dans le Roman de Baybar': Genèse d’un type littéraire," Studia Islamica 84, no. 2 (November 1996).

35. Nasseh Ahmad Mirza, Syrian Ismailism: The Ever Living Line of the Imamate (Richmond: Curzon, 1997), 65-66.

36. F.M. Chambers, “The Troubadours and the Assassins," Modern Language Notes 64, no. 4 (1949)

37. Vladimir Bartol, Alamut (Ljubljana: Založba Modra Ptica, 1938).

38. Simona Škrabec, "The Price of Leaving the Anonymity of a 'Small Literature.' Vladimir Bartol, Alamut, 1938," Interlitteraria 10 (2005): 353.

39. Mirt Komel, "Re-Orientalizing the Assassins in Western Historical-Fiction Literature: Orientalism and Self-Orientalism in Bartol's Alamut, Tarr's Alamut, Boschert's Assassins of Alamut and Oden's Lion of Cairo," European Journal of Cultural Studies 17, no. 5 (oktober 2014): 525. “...in forerunners...” emended as “...into forerunners....”

40. Franc Križnar, "On Alamut, an Opera in Three Acts, By Matjaž Jarc," Fontes Artis Musicae 55, no. 2 (April-June 2008); Edge Staff, "The Making Of: Assassin's Creed," Edge, augustus 27, 2012, https://web.archive.org/web/20131228044009/http://www. edge-online.com/features/making-assassins-creed/. (geraadpleegd 21-04-2019).

41. Voor een gedetailleerde studie, zie Shafique N. Virani, The Ismailis in the Middle Ages: A History of Survival, A Search for Salvation (New York: Oxford University Press, 2007), 7-9, 22, 92 et passim.

42. Steven M. Wasserstrom, "Islamicate History of Religions?," in History of Religions 27, no. 4 (1988): 405. 
Virani

43. Paul Ernest Walker, 'amīd al-Dīn al-Kirmānī: Ismaili Thought in the Age of al- 'àkim (London: I.B. Tauris in associatie met the Institute of Ismaili Studies, 1999), 55.

44. Mu 'ammad ibn `Abd al-Karīm ibn Abī Bakr A ’mad al-Shahrastānī, al-Milal wa’lni'al, ed. Sayyid Mu’ammad 'Imādī (Seyyed Muhammad Emadi) 'ā'irī (Haeri), Tarjamah-yi kitāb al-milal wa'l-ni'al az mutarjimī-yi nāshinākhtah, nuskhah-yi bargardān-i dastnawīs-i shumārah-yi 2371-i kitābkhānah-yi Ayāl 'ūfiyā (Istānbūl), Facsimile ed. (Tihrān: Markaz-i Pizhūhishī-yi Mīrāth-i Maktūb (Miras-e Maktoob) bā hamkārī-yi Mu'assasah-yi Mu āla 'àt-i Ismā' ìlī (The Institute of Ismaili Studies), $1395 \mathrm{HS} / 2016 \mathrm{CE}), 123$.

45. Mu ammad ibn `Abd al-Karīm ibn Abī Bakr A ’mad al-Shahrastānī, al-Milal wa’lni 'al, ed. 'Alī 'asan Fā'ūr and Amīr 'Alī Muhannā, 3rd ed., 2 vols. (Bayrūt: Dār al-Ma 'rifah, 1414 AH/1993 CE), 17; Mu ’ammad ibn `Abd al-Karīm ibn Abī Bakr A ' mad al-Shahrastānī, al-Milal wa'l-ni 'al, vert. A.K. Kazi and J.G. Flynn, Muslim Sects and Divisions: The Section on Muslim Sects in Kitāb al-Milal wa'l-Ni al (London: Kegan Paul International, 1984), 8. Vertaling enigszins aangepast.

46. Na `īr al-Dīn Mu'ammad ibn Mu ammad 'ūsī en 'alāh al-Dīn 'asan-i Ma 'mūd-i Kātib, Raw'ah-yi taslīm (Ta 'awwurāt), ed. Sayyid Jalāl 'usaynī (Seyyed Jalal Hosseini) Badakhshānī (Badakhchani), 1st [mīrāth-i maktūb] ed. (Tihrān: Markaz-i Pizhūhishīyi Mīrāth-i Maktūb (Miras-e Maktoob) bā hamkārī-yi Mu’assasah-yi Mu'āla 'āt-i Ismā 'ìlì (The Institute of Ismaili Studies), 1393 HS/2014 CE), 123. Na 'ìr al-Dīn Mu 'ammad ibn Mu 'ammad 'ūsī and 'alā' al-Dīn 'asan-i Ma 'mūd-i Kātib, Raw 'ahyi taslīm (Ta 'awwurāt), ed. en vert. Seyyed Jalal Hosseini Badakhchani, Paradise of Submission: A Medieval Treatise on Ismaili Thought; A New Persian Edition and English Translation of Na 'īr al-Dīn Tūsīs Raw'a-yi taslìm (London: I.B. Tauris in samenwerking met Institute of Ismaili Studies, 2005), 144. Vertaling enigszins aangepast.

47. Shafique N. Virani, "Early Nizari Ismailism: A Critical Edition and Annotated Translation of Khwajah Qasim Tushtari's Recognizing God," Iran: Journal of the British Institute of Persian Studies (2018): 6, online editie, DOI: 10.1080/05786967.2018.1493359. Print editie op komst. Vertaling enigszins aangepast. Zie ook Shafique N. Virani, "Persian Poetry, Sufism and Ismailism: The Testimony of Khwājah Qāsim Tushtarī’s Recognizing God," Journal of the Royal Asiatic Society Series 3, 29, no. 1 (januari 2019); Shafique N. Virani, "Alamūt, Ismailism and Khwājah Qāsim Tushtarī’s Recognizing God," Shii Studies Review 2, no. 1-2 (2018).

48. Dit extract komt uit mijn aanstaande kritische editie en vertaling van de tekst. Cf. Shams al-Dīn ibn A 'mad (of Mu 'ammad) ibn Ya 'qūb al- 'ayyibì (attrib.), al-Dustūr wa-da 'wat al-mu 'minīn li'l- 'u 'ūr in Arba ' rasā 'il Ismā 'ìliyyah, ed. 'Ārif Tāmir, 2e ed., Bayrūt: Maktabat al-' ayāt, 1978, 51.

49. Na 'īr al-Dīn Mu 'ammad ibn Mu'ammad 'ùsī, Sayr ù sulūk, ed. en vert. Seyyed Jalal Hosseini Badakhchani, Contemplation and Action: The Spiritual Autobiography of a Muslim Scholar (London: I.B. Tauris in association with Institute of Ismaili Studies, 1999).

50. Nā'ir al-Dīn 'Abd al-Ra 'ìm ibn Abī Man 'ūr Mu 'tasham and Na 'īr al-Dīn Mu 'ammad ibn Mu ’ammad 'ūsī, Akhlāq-i Mu 'tashamī (Tihrān: Dānishgāh-i Tihrān, 
Dānishkadah-yi 'ulūm-i ma 'qūl wa manqūl, 1339 HS/1960 CE), 54. Een complete vertaling van dit werk is in een vergevorderd stadium van voorbereiding

51. Na 'īr al-Dīn Mu 'ammad ibn Mu 'ammad 'ūsī, Ma 'lūb al-mu 'minīn in Shi'i Interpretations of Islam: Three Treatises on Theology and Eschatology; A Persian Edition and English Translation of Tawallā wa tabarrā, Ma 'lūb al-mu 'minīn and $\bar{A}$ ghāz wa anjām of Na 'īr al-Dīn 'ūsī, ed. en vert. Seyyed Jalal Hosseini Badakhchani, Desideratum of the Faithful. London: I.B. Tauris in samenwerking met Institute of Ismaili Studies, 2010, 23, mijn vertaling. Cf. Seyyed Jalal Hosseini Badakhchani, ed. Shi 'i Interpretations of Islam: Three Treatises on Theology and Eschatology; A Persian Edition and English Translation of Tawallā Wa Tabarrā, Ma 'lūb Al-mu 'minīn and $\bar{A}$ ghāz Wa anjām of Na 'ìr al-Dīn 'ūsī (London: I.B. Tauris in samenwerking met Institute of Ismaili Studies, 2010), 38-39

52. 'alā' al-Dīn 'asan-i Ma 'mūd-i Kātib, Dīwān-i qā 'imiyyāt, red. Sayyid Jalāl 'usaynī (Seyyed Jalal Hosseini) Badakhshānī (Badakhchani), Poems of the Resurrection, 2e ed. (Tihrān: Markaz-i Pizhūhishī-yi Mīrāth-i Maktūb (Miras-e Maktoob) bā hamkārī-yi Mu 'assasah-yi Mu 'āla 'āt-i Ismā' ìlī (The Institute of Ismaili Studies), 1395 HS/2016 CE), \#50, 152-153, lns. 1523-1526, 1531, 1546. Mijn vertaling.

53. Shafique N. Virani, "The Right Path: A Post-Mongol Persian Ismaili Treatise," Journal of Iranian Studies 43, no. 2 (april 2010): ed. 213, vert. 205. Vertaling enigszins aangepast. Zie ook Henry Corbin, "The Ismā 'ìlì Response to the Polemic of Ghazālī," chap. 4, vert. James Morris in Ismā 'ìlī Contributions to Islamic Culture, ed. Seyyed Hossein Nasr (Tehran: Imperial Iranian Academy of Philosophy, 1977), 79. 